\title{
Byelorussian Chronicle 1975
}

\section{EVENTS IN BYELORUSSIA}

A conference of Soviet writers and literary critics was held in Minsk on 26 February - 3 March.

\section{*}

The Janka Kupala Institute of Literature of the Byelorussian Academy of Sciences organised a conference on the development of Byelorussian literature in the 19th century. Among the papers read at the conference were "The most important moments in the development of Byelorussian literature in the first half of the 19th century' by A. Maldzis, 'Byelorussian literature in the second half of the 19th century' by J. Kaźbiaruk, and 'The history of the study of the anonymous poems Enieida navyvarat and Taras na Parnasie' by $\mathrm{H}$. Kisialoŭ.

Another conference organised by the Institute had for its subject "The truth of life and contemporary literary thought'.

An exhibition 'Young Byelorussian writers' was held in February at the Lenin State Library in Minsk. It consisted of published works of young authors such as Jaŭhienia Janiščyc, Viktar Rakaŭ, Nina Śklarava and others, as well as of their autographs, articles by literary critics and other materials illustrating their work and the development of their talents.

The Jakub Kolas Library of the Byelorussian Academy of Sciences in Minsk is $\mathbf{5 0}$ years old. It was founded in 1925 as the library of what was then called the Institute of Byelorussian Culture and which became the Academy in 1929. The Library was scverely damaged during the last war. At the present moment its holdings consist of some 1,300,000 titles.
A new establishment of higher education - the Institute of Culture - was opened in Minsk. It comprises a School of Librarianship and departments for training directors of theatres and amateur choirs and orchestras.

A now film entitled 'Voǔčaja zhraja' (The wolf pack), based on the novel of the same title by Vasil Bykaŭ, was made by 'Biełaruśfilm' in Minsk. The director of the film is Barys Sciapanaŭ.

The Janka Kupała Byelorussian State Theatre in Minsk staged the premiere of the new play by Vasil Bykaŭ, entitled Apošni šanc (The last trench).

The Brest Theatre staged the premiere of the new play Apošniaja instancyja (The last instance) by Mikoła Matukoŭski.

The Byelorussian composer Jaŭhien Hlebaŭ has written music for the new ballet 'Till Eulenspiegel', the premiere of which was staged by the Byelorussian State Theatre of Opera and Ballet.

Among the new works of the composer Ihar Eučanok are music for the poems Baiada by Maksim Tank and Biarozańka by Anatol Vialuhin.

\section{*}

A poetry festival in Viazynka, the birthplace of Janka Kupała, was held on 6 July. Among those taking part were the Byelorussian poets Maksim Eužanin, Mikoła Aŭramčyk, Anatol Viarcinski, Edzi Ahniaćviet, Stanisłaŭ Suškievič, Ryhor Baradulin, 
Volha Ipatava, Mikoła Aročka, Janka Sipakoŭ, Anatol Hračanikaŭ, Piatruś Makal, Mikoła Fiedziukovič, Hienadź Klaŭko and others. There were also several guests from Latvia, Lithuania, Russia, Ukraine, Uzbekistan and other Soviet republics.

In recent years it has become a tradition to hold an annual poetry festival in Viazynka on the anniversary of Kupała's birth.

An evening to commemorate the 75 th anniversary of the birth of the novelist Kuźma Corny (1900-1944) took place in Cimkavičy, the birth place of the writer. Among those taking part were the writers Vasil Vitka, Mikoła Łoban and Viečasłaŭ Adamčyk.

A monument to Francišak Bahuševič (1840-1900), the greatest Byelorussian 19th-century poet, was erected on his grave in Zuprany. There are plans to establish a Bahuševic museum in Kušlany, where the poet spent his childhood.

\section{$*$}

The founder of the modern Byelorussian theatre Ihnat Bujnicki (18611917) was commemorated by the erection of a monument in his honour in his native village of Prazaroki.

The famous poem Symon muzyka (Simon the musician) by Jakub Kolas is 50 years old. The first edition of the final version of the poem, which took Kolas 13 years to write, appeared in Minsk in 1925. To commemorate this occasion the Jakub Kolas Museum in Minsk organised a special 'Symon muzyka' exhibition.

The ancestors of Byelorussians appear to have been keen chess players. Archaeological excavations in Kopyś, Viciebsk, Eukoml, Zasłaŭje, Vaŭkavysk and other places have uncovered a number of artistically carved chess figures dating from the 12th and 13th centuries.
The 'Biarezinski zapaviednik' is the oldest nature reservation in Byelorussia. Established in 1925 in the upper reaches of the river Biarezina north of Barysaŭ, it comprises nearly 190,000 acres of forests and marshes. In the reservation there live 52 different species of mammals, 200 species of birds, 13 species of reptiles and its rivers and lakes are inhabited by 70 species of fish.

*

The Soviet astronaut Piotr Klimuk, who is a Byelorussian, in an interview confessed that he took with him on the space flight a copy of the miniature edition of selected poems by Jakub Kołas, 'Vieršy', published in Minsk in 1972.

\section{$*$}

The Byelorussian edition of Shakespeare's King Lear, published in 1974 in Minsk by the publishing house 'Mastackaja litaratura' (translation by Jurka Haŭruk, illustrations by Barys Zaboraŭ), was awarded the first republican prize for the most beautiful book published in 1974 .

\section{*}

The Byelorussian novelist Michaś Eyńkoŭ (b. 1899) died on 21 September. His first work appeared in print in 1919. In 1962 he was awarded the title 'People's writer of Byelorussia'.

The novelist Raman Sabalenka (b. 1907) and Taras Chadkievic (b. 1912) also died.

The Byelorussian historian L. Abecedarski died at the age of 59 . He was professor of history at the Byelorussian State University in Minsk and his chief publications are on the subject of Byelorussian-Russian relations in the 16th and 17th centuries.

\section{EVENTS ABROAD}

The Ethnographical Museum in Torun (Poland) has a rich collection of Byelorussian folk art. During the period October 1974 - January 1975 it held an exhibition of Byelorussian folk art in Grudziądz. Later the exhibition toured various cities of the Bydgoszcz region. 
Dr. Alaksandar Barščeŭski has been appointed head of the Byelorussian department at the University of Warsa.w. A distinguished historian of literature, he is better known as the poet Aleś Barski.

A Byelorussian study weekend on the theme 'Byelorussian presence in America' was 'held on 26-27 April at the University of Ottawa. It was organised through the efforts of the Canadian Section of the Byelorussian Institute of Arts and Sciences. The following papers were read: Prof. S. Horak (Univ. of East Illinois), 'Problems of periodization and terminology in the history of Byelorussia'; Dr. V. Kipel (New York Public Library), 'Early Byelorussian immigrants in North America'; A. Hrycuk (Queen's Univ., Kingston), 'Ideological and sociological bases of Byelorussian organised life in Canada'; R. Stankevič (Byelorussian-American Youth Association), 'Byelorussian youth in North America, their activities and achievements'; Dr. V. Tumaš (President, Byelorussian Institute of Arts and Sciences), 'Development of Byelorussian Studies in the USA'; F. Sysyn (Harvard Ukrainian Research Institute), 'Prospects of development of Ukrainian and Byelorussian studies in North America'; Dr. R. Žuk-Hryškievic (Byelorussian Institute of Arts and Sciences), 'Byelorussians in multicultural Canada'; Dr. J. Zaprudnik (New York City University), 'Soviet reaction to the activities of Byelorussians in North America'; Prof. A. Adamovic (Byelorussian Institute of Arts and Sciences), 'Byelorussian writers in North America'; Prof. J. Slavutych (Univ. of Alberta), "The new world through the eyes of a Byelorussian: short stories by Uładzimir Hłybinny'; Dr V. Arechva (Univ. of South Illinois), 'Image of autumn in the poetry of Natalla Arsiennieva'; Dr. S. Stankevich (Editor of 'Biełarus'), 'America through the eyes of Byelorussian Soviet writers who have visited it'.

The weekend was preceded by an exhibition of Byelorussian folk art (19-25 April), and an evening of the poetry of Natalla Arsieńnieva on 25
April, at which the poetess herself was present.

At a conference on nationalism in the USSR, held on 3-4 October at the University of Detroit, Dr. J. Zaprudnik read a paper on the general situation in Byelorussia since 1964, and Dr. V. Kipel - on problems of the economic development of Byelorussia during the last decade.

\section{*}

At the conference of the American Association for the Advancement of Slavic Studies on 8-11 October in Atlanta Dr. J. Zaprudnik read a paper entitled 'Problems of terminology and periodization of Byelorussian history'.

Shirin Akiner read a paper entitled 'Contemporary Young Byelorussian Poets' at a conference on modern Soviet literature, held in Oxford on 29-30 September.

The following papers were read at the 10th Lecture Course on Byelorussian Culture, organised by the Anglo-Byelorussian Society in London for the academic year 1975-76: 'The Devil, the peasant and the Jew - Aspects of Byelorussian literature in the 18th century' (A. McMillin); 'Francis Skaryna and his times' (A. Nadson); 'Nikolai Dylecki's treatise on music' ( $\mathrm{H}$. Leeming); 'The young Byelorussian poets of today' (S. Akiner); '17th century schools of Byelorussian wood-engraving' (G. Picarda); 'The early history of the first Byelorussian state' (J. Dingley).

The Byelorussian writer Jurka Vićbič died on 4 January in South River (USA). Born in 1905, his first work appeared in print in 1929 in the literary journal 'Uzvyšša'. Since then his works - mainly short stories and essays (in which he excelled) appeared regularily in various publications in Byelorussia and, later, abroad. During the last 25 years Vicbic resided permanently in the USA. 